\title{
THE MODE OF INHERITANCE IN ISOLATED LAEVOCARDIA AND DEXTROCARDIA AND SITUS INVERSUS
}

\author{
BY \\ MAURICE CAMPBELL \\ From the Cardiac Department, Guy's Hospital, and the Institute of Cardiology \\ Received June 12, 1963
}

More than twenty years ago, Cockayne (1938) studied 53 examples of complete transposition of the viscera, some that he had collected and others that had been reported. He concluded that it was inherited as a single recessive autosomal character. He mentioned also the three forms of partial transposition-incomplete situs inversus, isolated dextrocardia, and isolated lævocardia-and thought they were probably inherited in the same way.

Cockayne dealt mainly with patients who had complete situs inversus and no other malformation of the heart. Our 40 subjects all had other malformations of the heart; and 10 had complete situs inversus, 14 isolated dextrocardia, and 16 isolated lævocardia. We have made inquiries about their families in the same way that we have for those with other malformations of the heart (Polani and Campbell, 1955, 1960; Campbell and Polani, 1961a, b; and Campbell, 1962). Our 40 subjects were taken from a series of 53 patients $(11,22$, and 20 of the three groups respectively) seen over the past fifteen years, whom Campbell and Deuchar hope to discuss with an account of the associated malformations, probably in 1964 . The only selection was that they all had other malformations of the heart as well as the inversion and were willing to complete our questions about the family.

\section{Findings when Propositi had Situs Inversus and Other Malformations of the HEART}

We have obtained answers to our questions about consanguinity of the parents and other malformations in relatives in 10 of the 11 families of propositi with situs inversus associated with other malformations of the heart. In one the parents were first half-cousins (Case 25, Fig. 1), in another they were second cousins (Case 23), and in the other eight they were not known to be related, though in Case 24 the mother's parents were first cousins whose mothers were twins, probably identical twins. The numbers are small, but two cousin marriages in ten families are unlikely to occur by chance. This suggests, as might be expected, that situs inversus may be inherited as a Mendelian recessive character whether it is the sole malformation or is associated with other malformations of the heart.

Situs Inversus in these Families. The family history supported some hereditary factor in other ways also, for situs inversus was known to be present in the sister of one (Case 24), in the uncle of another (Case 21), and in the cousin of the mother of a third (Case 31). The first cousin (Case 18) of a fourth subject (Case 25) had inversion of the abdominal viscera but with isolated lævocardia. This known incidence of other examples of situs inversus, complete in three and partial in a fourth of our ten families, is very striking. We have inquired about the families of more than a thousand patients with malformations of the heart and can remember only one other instance where a relation had situs inversus - a girl with pulmonary atresia whose sister had situs inversus but a heart that was otherwise normal-and, since this was written, a boy with ventricular septal defect whose brother had situs inversus. 


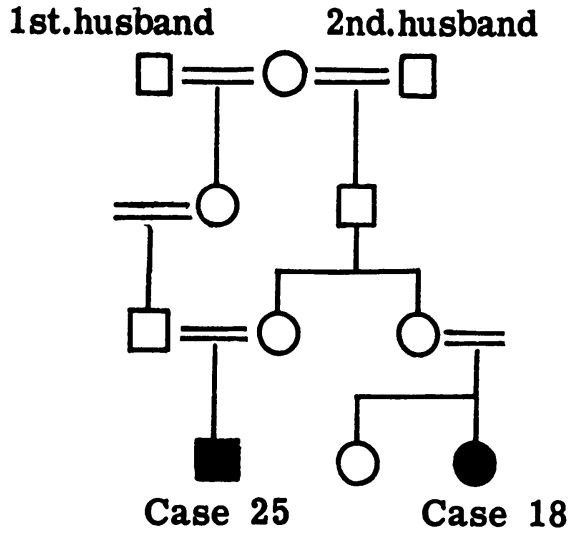

Fig. 1.-Family tree of Case 25 with situs inversus, showing that his parents were first half-cousins, and of Case 18 with isolated lævocardia, the first cousin of Case 25.
Two of these propositi had also non-cardiac malformations: Turner's syndrome and hypospadias (see Table I). The numbers are small, but the proportion is even higher than we have found in other forms of malformation of the heart.

There were 21 sibs of our 10 propositi. One had complete situs inversus with a heart that was otherwise normal (Case 24). There were also two with non-cardiac malformations (see Table I).

The mother of one subject with an atrial septal defect (Case 22) died at 28 years with heart disease and had no known rheumatic history so she too may have had an atrial septal defect. The maternal uncle of another (Case 21) had uncomplicated situs inversus. A paternal uncle of another (Case 24) had been diagnosed as Fallot's tetralogy, but when he died, aged 32, necropsy showed a small left ventricle that had no outflow except through a high ventricular septal defect; the single trunk arose from a large right ventricle; no pulmonary trunk or arteries were found and the blood supply to the lungs was through bronchial arteries; so truncus arteriosus was more likely than pulmonary atresia. The first cousin of Case 25 had tricuspid atresia and pulmonary atresia as well as isolated lævocardia.

This number of malformations of the heart-in $1 \mathrm{sib}, 1$ parent, 2 uncles, and 1 first cousin-in only 10 families is, we think, more than would be expected by chance. With most other common malformations of the heart we have found an increased number of cardiac malformations in the sibs of our propositi, but among the parents only in those with atrial septal defect, and not in any group in their other relatives. Nor have we found any increase of non-cardiac malformations in any relatives, even in the sibs.

\section{Findings when Propositi had Isolated Dextrocardia or Isolated Levocardia}

We have been able to get most particulars of the family and relatives in 14 of the 22 families where the propositi had isolated dextrocardia and in 16 of the 20 where they had isolated lævocardia. We shall discuss both these groups together because our observations in both seem to be much the same, but D (dextrocardia) or L (lævocardia) is added after each Case number so that they can, if necessary, be distinguished later. We found no cardiac malformations in their sibs and no cousin marriages among their parents, so both these were much less than we found in the families of our propositi with situs inversus totalis. We shall discuss later whether there is adequate evidence that this is generally so or whether the difference is a chance one due to our small numbers.

In the families where we have the information available, there was no example of consanguinity between their parents. The mother of Case $18 \mathrm{~L}$, however, was the sister of the mother, and the first cousin of the father, of Case 25 with situs inversus and other malformations (Fig. 1): these two cousins were seen independently and both were therefore included in the series. This was the only known example of any situs inversus, complete or partial, among the relatives.

An additional malformation of the heart, often more than one, as well as the isolated dextrocardia or lævocardia was present in each of the propositi. Atrial and ventricular septal defects and pulmonary stenosis were the most common, but transposition of the great vessels, a single atrium, a single ventricle, and anomalous pulmonary venous drainage were not uncommon.

Non-cardiac malformations were at least as common as in the propositi with situs inversus (see Table I). It is noteworthy that the spleen was divided into four parts in one and was absent in two 
TABLE I

Non-Cardiac Malformations in 39 Propositi, 68 Sibs, and Some Other Relatives

\begin{tabular}{|c|c|c|}
\hline $\begin{array}{l}\text { Case No. } \\
\text { and Group }\end{array}$ & Relationship & Nature of malformation \\
\hline $\begin{aligned} 23 & \text { S.I.* } \\
29 & \text { S.I. } \\
43 & \text { I.D.* } \\
46 & \text { I.D. } \\
2 & \text { I.L.* } \\
7 & \text { I.L. } \\
8 & \text { I.L. } \\
9 & \text { I.L. } \\
16 & \text { I.L. }\end{aligned}$ & $\begin{array}{l}\text { Propositus } \\
\quad, \\
\text {," } \\
, \\
, \\
, \\
,\end{array}$ & $\begin{array}{l}\text { Hypospadias } \\
\text { Turner's syndrome } \\
\text { Club foot } \\
\text { Recto-vaginal fistula, hemi-vertebræ, and absence of and fusion of ribs } \\
\text { Arachnodactyly } \\
\text { Spleen divided into four parts } \\
\text { Absence of spleen } \\
\text { Absence of spleen } \\
\text { Kyphoscoliosis from hemi-vertebra }\end{array}$ \\
\hline $\begin{aligned} 26 & \text { S.I. } \\
31 & \text { S.I. } \\
9 & \text { I.L. }\end{aligned}$ & $\begin{array}{l}\text { Sister } \\
\text { Brother } \\
\text { Brother }\end{array}$ & $\begin{array}{l}\text { Mongolism } \\
\text { Congenital pyloric stenosis } \\
\text { Club foot }\end{array}$ \\
\hline $\begin{array}{l}17 \text { I.L. } \\
23 \text { S.I. } \\
23 \text { S.I. } \\
47 \text { I.D. } \\
47 \text { I.D. }\end{array}$ & $\begin{array}{c}\text { Nephew } \\
\text { First cousin } \\
\text {, } \\
, \\
,\end{array}$ & $\begin{array}{l}\text { Deformity of hand } \\
\text { Mental defect } \\
\text { Spasticity } \\
\text { Hare lip } \\
\text { Hare lip }\end{array}$ \\
\hline
\end{tabular}

* S.I. =Situs inversus, I.D. = Isolated dextrocardia, and I.L. =Isolated lævocardia.

others: it was absent in a fourth patient with isolated lævocardia, omitted here only because we could not get details about his family.

There were no known cardiac malformations in the parents and 48 sibs, and only one noncardiac malformation (see Table I). Only one of the propositi (Case 42D) has a family and it consists of two healthy children.

Among the other relatives of the 23 propositi $(10 \mathrm{D}, 13 \mathrm{~L})$ where the question was answered, there were 4 examples of cardiac malformations. A first cousin of Case $18 \mathrm{~L}$ had a large ventricular septal defect and pulmonary stenosis as well as situs inversus. A first cousin of Case $3 \mathrm{~L}$ had pulmonary valve stenosis that was not severe. A maternal aunt of Case $5 \mathrm{~L}$ was born with some malformation of the heart that led to her death when she was 33 years old. The mother's cousin had had an operation for a persistent ductus (Case 33 D). Among the non-cardiac malformations, the hare lips in 2 cousins were thought to come from the unrelated husband's side of their family.

Comment. If it is right to combine our three groups because of the small numbers, the parents were cousins in 2 of the 38 families-a much higher proportion than we have found in our other malformations of the heart. Additional cardiac malformations were present by definition in all the propositi and non-cardiac malformations in 9 of the 40 . Only 1 of the 69 sibs had a cardiac malformation and this was situs inversus-a slightly smaller proportion with any malformation of the heart, but a slightly larger proportion with a concordant malformation than we have found in our other groups with malformations of the heart. The non-cardiac malformations were no more common than among the general population, except among the propositi themselves.

If, however, it is wrong to combine these groups because the differences found did indicate different ætiologies, all the positive findings would be much more striking for those with situs inversus and of little or no significance for those with isolated dextrocardia or isolated lævocardia. We shall discuss what evidence can be found to decide between these two possibilities.

\section{Maternal and Paternal Ages, Birth Weight, and Season of Birth}

These factors have each been considered for our groups with other malformations of the heart, but the numbers here are too small for much discussion. The mean maternal age was $28 \cdot 1$ yearsmuch as might be expected - and the mean paternal age was $30 \cdot 1$ years. This excess is a little less than the normal finding, but not significantly so. 
The mean birth weight of the boys was only a trifle below what I have found for boys $(7 \cdot 42$ against $7.51 \mathrm{lb}$.), and a little below my findings for girls with other malformations of the heart $(6.91$ against $7.25 \mathrm{lb}$.), This last difference is based on ten cases only and is less than the differences often found in successive tens of normal controls. The figures for the months of birth must be erratic with such small numbers, but did not suggest that the births of either boys or girls were concentrated at any particular period.

In none of these particulars does this small experience suggest that there would be interesting differences in a much larger series, though obviously it cannot disprove this.

\section{Discussion}

Cockayne's main evidence for the inheritance of situs inversus through a recessive gene was (1) its rarity in a parent and child, and the ratio of affected to normal sibs in the fraternities, (2) its occurrence in both members of 5 out of 6 pairs of monozygotic twins, and (3) the high proportion (6 of 53) of first-cousin marriages that give rise to it. These seemed conclusive, but his series might have been atypical in the unusual number of familial cases that had perhaps been reported or brought to his notice for this very reason.

Torgersen (1946) studied the question by mass radiography in Norway: by 1950 he had collected 229 fraternities consisting of 1461 sibs where one at least of them had situs inversus. In 221 of these sibships there was no second case, in 5 there were two sibs affected, and in 3 there were three sibs with situs inversus. In these fraternities there were therefore the 229 propositi and 11 secondary cases with situs inversus and 1221 normal sibs. Thus less than 1 per cent of the other sibs were affected and about 1 in 6 of all the sibs, including the propositi. Among these 229 families there were 7 where the parents were first cousins and 2 where they were second cousins. It seems, therefore, that cousin marriages between the parents of children with situs inversus were much commoner than usual, and Torgersen thought the greater degree of in-breeding explained why situs inversus was rather more common in the rural districts of Norway.

Lowe and McKeown (1954) examined the families of 10 cases of isolated dextrocardia born to mothers in Birmingham in 1937-51, and of 20 cases of dextrocardia with situs inversus, of whom 7 were selected as above and 13 at mass radiography. For isolated dextrocardia, 16 of the 18 sibs of the 10 propositi were examined and no inversion or other malformation of the heart was found: none of their parents were cousins. For dextrocardia with situs inversus ( 20 cases), 1 of the 51 sibs was similarly affected, and there were 2 first-cousin marriages $(10 \%)$. In the former group other cardiac malformations were common, but in the latter they were not.

Lamy, de Grouchy, and Schweisguth (1957) found a much higher incidence of cousin marriages in their groups with situs inversus and isolated dextrocardia (their indices of 18 and 10 respectively) than in their other groups with malformations of the heart (average index of 2.4); and these were much higher than among their controls (their index 0.7). Among the parents of 12 propositi with situs inversus they found 1 marriage between first cousins, 1 between first cousins once-removed, and 1 between second cousins; and among 13 propositi with dextrocardia there was 1 first-cousin marriage. The findings of these four series and of my own are summarized in Table III. Arge (1960) reported an unusual family where two brothers married two sisters who were their second cousins; each pair had nine children who included two boys with situs inversus in one family and a boy and a girl with situs inversus in the other: these families are not included in the subsequent analysis, as the unusual findings were probably the reason for their being reported.

Incidence of Situs Inversus, Isolated Dextrocardia, and Isolated Lavocardia. Cockayne (1938), judging by school surveys, found the incidence of situs inversus about 1 in 20,000 though he found other estimates of 1 in 9000 and 1 in 24,000. Torgersen (1950) in Norway found it in 10,000 but found very few examples of isolated dextrocardia and lævocardia. Lowe and McKeown (1954) found it rather higher, 1 in 7000, and gave the first estimate of the incidence of isolated dextrocardia, 1 in 29,000 . 
We have no direct evidence about this, but can make some estimate from the numbers seen up to 1953 where we know they were found among 1130 patients with congenital heart disease. We found $8(0.7 \%)$ with situs inversus and other malformations of the heart, $19(1.7 \%)$ with isolated dextrocardia, and $15(1.3 \%)$ with isolated lævocardia. The calculations that follow may prove rather tedious, so the conclusions are given first. The incidence of situs inversus with other malformations of the heart is about 1 in 42,000, that of isolated lævocardia 1 in 22,000, and that of isolated dextrocardia 1 in 17,500 - an incidence higher than that found by Lowe and McKeown but of the same order. These findings are summarized in Table II.

TABLE II

InCidence of Situs InVersus, Isolated Dextrocardia, and Isolated LÆVocardia

\begin{tabular}{|c|c|c|c|c|}
\hline & \multicolumn{2}{|c|}{ Situs inversus totalis } & \multirow[b]{2}{*}{$\begin{array}{c}\text { Isolated } \\
\text { dextrocardia }\end{array}$} & \multirow[b]{2}{*}{$\begin{array}{c}\text { Isolated } \\
\text { lævocardia }\end{array}$} \\
\hline & $\begin{array}{l}\text { Heart otherwise } \\
\text { normal }\end{array}$ & $\begin{array}{l}\text { With other } \\
\text { malformations } \\
\text { of heart }\end{array}$ & & \\
\hline $\begin{array}{lll}\text { Cockayne }(1938) & \ldots & \ldots \\
\text { Torgersen }(1950) & \ldots \\
\text { Lowe and McKeown (1954) } \\
\text { Campbell (this paper) }\end{array}$ & $\begin{array}{l}1 / 20,000 \\
1 / 10,000 \\
1 / 7,000 \\
-\end{array}$ & $\frac{\bar{Z}}{\bar{T}}$ & $\begin{array}{l}\text { Rare } \\
1 / 29,000 \\
1 / 17,500\end{array}$ & $\begin{array}{c}\text { Rare } \\
\overline{1 / 22,000}\end{array}$ \\
\hline
\end{tabular}

Of the 42 patients with partial or complete situs inversus 38 were among our 670 cyanotic patients $(5.7 \%)$ and only 4 were among our 460 acyanotic patients $(0.9 \%)$. This gives an incidence of 3.7 per cent in our whole series, but it was atypical because there was an unusually high proportion of cyanotic patients. To make it more representative, we have calculated what the incidence would be if one-quarter of the patients were cyanotic and three-quarters acyanotic. It would then have been $2 \cdot 1$ per cent for these three conditions together -0.4 per cent with situs inversus and other malformations of the heart, 1.0 per cent with isolated dextrocardia, and 0.7 per cent with isolated lævocardia. Berri (1958) found a similar incidence among 2695 patients with congenital heart disease seen at the Hospital de Niños in Buenos Aires, rather more with dextrocardia $(2 \cdot 2 \%)$ and rather less with isolated lævocardia $(0 \cdot 4 \%)$.

Assuming that the incidence of all malformations of the heart is about 6 per 1000, our figures would give incidences of 1 in 42,000 for situs inversus with other malformations of the heart, of 1 in 17,500 for isolated dextrocardia, and 1 in 22,000 for isolated lævocardia. With so many assumptions, these can be only approximations.

These calculations enable one to estimate how many subjects with situs inversus totalis have other malformations of the heart. To the general physician, nearly all patients with situs inversus seem to have a heart that is otherwise normal, though many have bronchiectasis. To the cardiologist seeing children with congenital heart disease, nearly all patients with situs inversus seem to have other malformations of the heart. The truth must be somewhere between, and if we accept Torgersen's estimate that the incidence of situs inversus is 1 in 10,000, and ours that situs inversus with other malformations of the heart is 1 in 42,000, it follows that about 1 in 4 of all subjects with situs inversus has other malformations of the heart as well. This is a high proportion but is less than the incidence of malformations of the heart found in Turner's syndrome in chromatin-negative women and in men (Polani, 1961) and in mongols dying in the first three years of life, and of about the same order as that found ( 1 in 5) in mongols dying between their fourth and tenth years (Berg, Crome, and France, 1960).

The Position with Monozygotic Twins. Cockayne (1938) found reports of 5 pairs of monozygotic twins where both had situs inversus and only 1 pair where one was affected and the other normal. Fuhrmann (1958) found 6 pairs where both had situs inversus and 4 pairs where only one was affected. Pairs that are reported seem much more likely to be those that are concordant, so often give a wrong impression. Thus, in three unselected series (Uchida and Rowe, 1957; Lamy et al., 
1957; Campbell, 1961) there was no pair of monozygotic twins where both had a malformation of the heart and 32 pairs where one only was affected and the other normal; yet in a collection of reported cases (Fuhrmann, 1958) there were 16 concordant pairs and 30 discordant pairs.

These three unselected series of twins with malformations of the heart contain only one pair involving situs inversus, and here one member had isolated dextrocardia and the other was normal. From this series I can add another example of monozygotic twins where one had isolated dextrocardia (Case 42 D) and the other was normal; and Lowe and McKeown (1954) in an unselected sample found another pair where one member had situs inversus and the other was normal. These three pairs of monozygotic twins are the only ones I know taken from unselected series, and in each case one had partial or complete situs inversus and the other was normal.

This suggests that situs inversus follows the same general rule as other malformations of the heart and that commonly in such twin pairs one is affected and one normal (Campbell, 1961). This agrees with an earlier view that has found its way into lay literature (Sayers, 1933). Nevertheless, Fuhrmann's figures show more concordance for situs inversus (0.6:6 of 10 pairs) than for other malformations of the heart $(0 \cdot 35: 16$ of 46 pairs) and this difference is probably significant and means that exceptions are more common with situs inversus than with other malformations of the heart; and even with these exceptions are not rare.

\section{Consanguinity of PaRents}

For these calculations, we have used the combined figures shown in Table III. There is a high incidence of first-cousin marriages, both for situs inversus totalis, $5 \cdot 3$ per cent $\left(5 \cdot 7^{*}\right)$, and for isolated dextrocardia (including some cases of isolated lævocardia), 5.5 per cent. Both these figures

TABLE III

InCidence of Cousin Marriages and Number of Sibs Affected in Situs Inversus (1) AND ISOLATED DEXTROCARDIA (2)

\begin{tabular}{|c|c|c|c|c|c|c|c|c|}
\hline \multicolumn{4}{|c|}{ Authors } & \multirow{2}{*}{$\begin{array}{r}\begin{array}{r}\text { No. of } \\
\text { families }\end{array} \\
53 \\
4 \\
229 \\
20 \\
10 \\
12 \\
13 \\
10 \\
28\end{array}$} & \multicolumn{2}{|c|}{$\begin{array}{l}\text { Cousin } \\
\text { marriages } \\
1 \text { st } 2 \text { 2nd }\end{array}$} & $\frac{\text { No. of sibs* }}{(93)}$ & $\frac{\begin{array}{c}\text { No. of } \\
\text { sibs } \\
\text { affected* }\end{array}}{(6)}$ \\
\hline $\begin{array}{l}\text { Cockayne (1938) } \\
\text { Torgersen (1950) } \\
\text { Lowe and McKeown ( } \\
\text { Lamy et al. (1957) } \\
\text { Campbell (this paper) }\end{array}$ & $\begin{array}{l}\text { (1)+ } \\
(2)+ \\
(1)+ \\
\text { 954)+ } \\
(2)+ \\
(1)+ \\
(2)+ \\
(1)+ \\
(2)++\end{array}$ & $\begin{array}{l}\ldots \\
\ldots \\
\ldots \\
\ldots \\
\cdots \\
\cdots \\
\ldots\end{array}$ & $\begin{array}{l}\ldots \\
\ldots \\
\ldots \\
\ldots \\
\ldots \\
\ldots \\
\ldots\end{array}$ & & $\begin{array}{l}6 \\
2 \\
7 \\
2 \\
0 \\
1 \\
1 \\
1 \\
0\end{array}$ & $\begin{array}{l}0 \\
0 \\
2 \\
0 \\
0 \\
2 \\
0 \\
1 \\
0\end{array}$ & $\begin{array}{r}(93) \\
1232 \\
51 \\
16 \\
22 \\
23 \\
21 \\
48\end{array}$ & $\begin{array}{l}(6) \\
11 \\
1 \\
0 \\
0 \\
0 \\
1 \\
0\end{array}$ \\
\hline $\begin{array}{l}\text { Total } \\
\text { Grand total }\end{array}$ & $\begin{array}{c}(1) \\
(2) \\
(1 \text { and } 2)\end{array}$ & $\begin{array}{l}\ldots \\
\cdots \\
\ldots\end{array}$ & $\begin{array}{l}\ldots \\
\ldots \\
\cdots\end{array}$ & $\begin{array}{r}324 \\
55 \\
379\end{array}$ & $\begin{array}{r}17 \\
3 \\
20\end{array}$ & $\begin{array}{l}5 \\
0 \\
5\end{array}$ & $\begin{array}{c}1326 \dagger \\
87 \\
1413 \dagger\end{array}$ & $\begin{array}{c}13 \dagger \\
0 \\
13 \dagger\end{array}$ \\
\hline
\end{tabular}

* Excluding propositi.

+ (1) with situs inversus; (2) with isolated dextrocardia.

++ Isolated lævocardia as well as dextrocardia.

$\dagger$ Excluding Cockayne's cases as perhaps selected.

are very high, nearly 5 times the $1 \cdot 1$ per cent we have found with most other malformations of the heart, and 11 times the level of first-cousin marriages in the general population in Britain. I have taken this level as 0.5 per cent: it has been estimated as between 0.4 per cent (Bell, 1940) and 0.6 per cent (Roberts, 1955) but the latter thinks it is now more likely to be between 0.4 and 0.5 per cent.

* The second figure in brackets gives the percentage of all cousin marriages, counting one-half for marriages of first cousins once-removed and one-quarter for those of second cousins, but the discussion is confined to first-cousin marriages. 
Next we compare the incidence of first-cousin marriages for those with situs inversus and a heart that is otherwise normal and for those where there are other malformations of the heart as well. Since the number in the latter group is small, we have added those with isolated dextrocardia and isolated lævocardia, all of whom have malformations of the heart also. Taking the 53 cases of Cockayne, the 20 of Lowe and McKeown, and all of Torgersen's as having situs inversus with a heart that is otherwise normal gives 5.0 per cent with first-cousin marriages (15 in 302 families): the remainder, all with other malformations of the heart, have an incidence of nearly 6.5 per cent ( 5 in 77 families). Although this gives a higher incidence in those with additional malformations of the heart, the difference is not enough to be significant in view of the small size of the latter group.

The high incidence of cousin marriages suggests that inheritance through the same autosomal recessive gene plays an important part in the production of (1) situs inversus, whether the heart is otherwise normal or has additional malformations, (2) isolated dextrocardia, and (3) probably of isolated lævocardia though the numbers are too small to give direct evidence of this. Cockayne (1938) suggests that, if isolated dextrocardia is carried by a different gene from situs inversus totalis, the proportion of cousin marriages should be higher in the former, since its incidence in the general population is lower. The close similarity of the high percentages supports the view that both are determined, partly at least, by the same recessive gene. If this is true for all the three groups, it would explain, as Cockayne suggested, why the conditions remain so rare among the general population; since many of the associated malformations often prove fatal, and the gene would, therefore, be partially lethal.

Calculation of Incidence from Percentage of Cousin Marriages. The lower the incidence of a recessive gene in the general population, the higher the incidence of cousin marriages among the parents of those who are homozygous for this gene and therefore reveal its presence. These two parameters are related by the formula of Lenz (1919) and if the rates of first-cousin marriages in the community and in the parents of those with situs inversus are known, one can calculate the incidence of situs inversus in the community.

Assuming an incidence of first-cousin marriages of 0.5 per cent among the general population and $5 \cdot 3$ per cent among the parents of those with complete situs inversus, and interpolating from Table XVIII of Maynard-Smith, Penrose, and Smith (1961), the incidence of complete situs inversus would be 1 in 26,000. If all three forms of situs inversus are inherited through the same gene with an incidence of first-cousin marriages of 5.3 per cent, the combined incidence of the three forms would be 1 in 26,000. These estimates are much lower than the figures of 1 in 10,000 for complete situs inversus and of 1 in about 5000 for the three forms of inversion combined. One possible explanation for this would be that only a proportion of the cases of situs inversus is directly caused by a recessive gene. The considerable variation in the incidence of situs inversus found by different observers and the uncertainty about the exact incidence of cousin marriages in a larger series must, however, call for caution in the interpretation of these calculations.

Familial Distribution. Reports of situs inversus in a parent and child are uncommon. Cockayne (1938) found one example in a mother and daughter reported by Matisson and another in a father and son reported by Meyer-Hürlimann. Torgersen (1946) found one example in a mother and daughter. No such examples were reported by Lowe and McKeown or by Lamy et al. or in the present series. An occasional example is not incompatible with recessive inheritance, for there may have been a marriage between two heterozygotes in an earlier generation as well.

Only the sibs are shown in Table III and other relatives are not included as we do not know the numbers at risk. There were, however, a few examples of aunts or uncles and cousins-probably more than would be expected in the general population. Excluding the propositi, there was 1 per cent of sibs with situs inversus in these families, and in those with isolated dextrocardia or isolated lævocardia there were 87 normal sibs and none affected: this deficiency is not enough to prove any difference from an incidence of 1 per cent. If the propositi in both groups are included, there were 337 affected and 1313 normal sibs (1 to 3.9) in the families with situs inversus, and 55 affected and 87 normal sibs (1 to $1 \cdot 6)$ in those with isolated dextrocardia and isolated lævocardia.

$3 \mathrm{E}+$ 
Theoretically with a recessive condition, the proportion should be 1 affected to 3 normal, but in clinical practice it generally rises to nearer 1 to 2 , because families where the parents were both heterozygotes but did not happen to have an affected child cannot be recognized and are inevitably omitted. The proportion for the two groups combined (1 to 3.6$)$ is, therefore, lower than might be expected, suggesting that there may be incomplete penetrance of the recessive gene. The incomplete penetrance and the relative rarity of each of a pair of monozygotic twins being affected both show that environmental factors also must be important.

Apart from the general similarities in the findings about situs inversus totalis and isolated lævocardia and dextrocardia, there are some reports where both were found in the same family. Thus Cockayne (1938) quotes the report of Doolittle where a man with isolated dextrocardia had twin children, a boy and a girl, one with situs inversus and the other with a normal heart. One of the only three cases of isolated lævocardia found by Torgersen (1950) was a secondary case to a sib with situs inversus. Polhemus and Schafer (1952) reported a case with isolated lævocardia, cor biloculare, severe pulmonary stenosis, and absence of the spleen, where the only sib had atrio-ventriculare commune and accessory spleens: in both sibs the inversion of the abdominal viscera was incomplete and there was a Meckel's diverticulum. In our series the first cousin of a propositus with situs inversus and other malformations of the heart had isolated lævocardia. The combination does not seem common but with such rare conditions even these examples suggest that it is worth searching for, e.g. in large mass $\mathrm{x}$-ray surveys.

\section{Associated Malformations}

By definition, all our patients had other malformations of the heart. In those with isolated lævocardia, atrial septal defects were present in about three-quarters and a single atrium in onequarter. The same proportions applied to ventricular septal defects. Pulmonary stenosis or atresia was present in 80 per cent. The malformations in those with isolated dextrocardia were much the same; but in those with dextrocardia and situs inversus, they were more varied and perhaps less severe, and a common atrium or a common ventricle was rare.

The non-cardiac malformations were widely spread among the different systems, but there were three examples of splenic agenesis with isolated lævocardia and, considering the rarity of this, it is surprising. Lowe and McKeown (1954) found bronchiectasis in 3+1, splenic agenesis in 1+2, and a persistent common mesentery in $2+2$, of their 20 cases with situs inversus and their 10 cases of isolated dextrocardia respectively, the figure for the last group being given second.

Anyone interested in malformations of the heart must soon notice the frequency of malformations of other parts of the body in the same subject. Several years ago I thought that, if these were recorded, organs that were formed at the same stage of development or organs that lay close together at a particular stage might both be affected more often in the same subject. In general, this has not been found; and malformations of any part of the body seem likely to occur with any of the different malformations of the heart, suggesting some general disturbance of development. There are exceptions, e.g. the frequency of various malformations of the heart with mongolism, of Turner's syndrome with coarctation of the aorta, and of bronchiectasis with situs inversus.

As early as 1934, Putschar drew attention to the frequent association of cardiovascular malformations, especially situs inversus, with agenesis of the spleen; and Polhemus and Schafer (1952) emphasized the frequency of ostium atrio-ventriculare commune in this syndrome. Ivemark (1955), reviewing 55 reported cases of splenic agenesis and 14 new serial cases from necropsy records, found that (1) 97 per cent had cono-truncal malformations (see Table IV); (2) that 56 of the 58 with an adequate description $(97 \%)$ had malformations of the region of the atrio-ventricular valve, a common A-V ostium in 79 per cent (with cor biloculare in 48 per cent) and mitral or tricuspid atresia in others; and (3) 85 per cent had some degree of situs inversus. The form of this was varied and in his tables he includes 23 as dextrocardia and 36 as isolated lævocardia. The stomach was transposed in 33, the liver was transposed in 17 and symmetrical in 31 , and there was a common mesentery in 33: the lobation of the lungs was abnormal in 46 and symmetrical in 40 cases, of which 
TABLE IV

Numbers of Ivemark's Cases of Splenic Agenesis with Isolated Levocardia and Dextrocardia and CONO-TRUnCAL Malformations

\begin{tabular}{|c|c|c|c|c|c|c|c|}
\hline & & $\begin{array}{l}\text { (A) With } \\
\text { truncus } \\
\text { arteriosus }\end{array}$ & $\begin{array}{l}\text { (B1) With } \\
\text { pulmonary } \\
\text { atresia* }\end{array}$ & $\begin{array}{l}\text { (B2) With } \\
\text { pulmonary } \\
\text { stenosis* }\end{array}$ & $\begin{array}{c}\text { (C) With } \\
\text { transposition } \\
\text { alone }\end{array}$ & $\begin{array}{l}\text { (D) Without } \\
\text { anomalies } \\
\text { of cono- } \\
\text { truncus }\end{array}$ & Total \\
\hline $\begin{array}{l}\text { Dextrocardia ... } \\
\text { Isolated lævocardia } \\
\text { Normal. . . . }\end{array}$ & $\begin{array}{ll}. & . \\
. & \ldots \\
. & \ldots\end{array}$ & $\begin{array}{l}5 \\
3 \\
2\end{array}$ & $\begin{array}{l}9 \\
8 \\
2\end{array}$ & $\begin{array}{r}6 \\
15 \\
1\end{array}$ & $\begin{array}{l}2 \\
9 \\
3\end{array}$ & $\begin{array}{l}1 \\
1 \\
2\end{array}$ & $\begin{array}{l}23 \\
36 \\
10\end{array}$ \\
\hline Total & .. & $10(15 \%)$ & $19(28 \%)$ & $22(33 \%)$ & $14(21 \%)$ & $4^{*}(3 \%)$ & 69 \\
\hline
\end{tabular}

* With or without transposition of the great vessels.

$\dagger$ Two of these were uncertain because of inadequate description and are omitted in the percentages.

35 had three lobes to each lung. All these associations are highly significant and Ivemark suggests that it should be called "asplenia, a teratologic syndrome of visceral symmetry", though this does not include his own important work in emphasizing the frequency of cono-truncal malformations.

Embryological Considerations. Looked at from the point of view of situs inversus, splenic agenesis is relatively uncommon, but the other associations of this syndrome make it worth considering the embryological implications. Streeter (1948), using his method of Horizons, found the A-V canal cushions became fused in Horizon XVI (32-34 days in embryological life), while the separation of the cono-truncus was complete about two days later in Horizon XVII (34-36 days). He did not discuss the development of the spleen, but Ivemark (1955) studied this in six human embryos with the following conclusions: (1) the first morphological evidence of splenic primordia occurs in Horizon XV (31-32 days); (2) there is increasing angiogenesis and the first sinusoids appear in Horizon XVI (and there is a primitive gut mesentery and initiation of pulmonary lobation at this time); and (3) the sinusoids are more prominent and the incisures of the surface of the splenic primordia appear in Horizon XVII (34-36 days). There is, therefore, a close temporal correspondence in these events. The normal spiral division of the cono-truncus is thought to be influenced by the blood stream (Bremer, 1932) and could, therefore, be disturbed by malformations of the A-V cushions.

Ivemark (1955) did not discuss from the embryological point of view the association with situs inversus presumably because it was less constant. Situs inversus totalis, and probably its incomplete forms also, develop at a much earlier embryological stage, about the 10th to 15 th day of intrauterine life. This suggests that the abnormal factor sometimes influences development over a period of from three to four weeks, since it is hard to see how the presence of situs inversus, even in its partial form, can itself lead to splenic agenesis. There is, however, no certainty that this syndrome and the generality of cases of situs inversus have the same ætiology, but the association is of some interest.

\section{EVIDENCE FROM EXPERIMENTAL ANimals}

Occasional examples of situs inversus in animals have been recognized for a long time, but only two papers have been found that seem significant for the problems discussed here. Tihen, Charles, and Sippel (1948) found examples of situs inversus occurring in a strain of laboratory mice, though previously they had found no example in autopsies on 11,000 mice. Among 227 offspring of inbreeding within this line, there were 57 mice with situs inversus. This was thought to be about half the number that would be expected if the condition was inherited through an autosomal recessive gene with full expression.

In the second example, Baker-Cohen (1961) found situs inversus viscerum in 37 per cent of an inbred line of the domesticated Fury strain of the platyfish (Xiphophoris maculatus), though it was 
rare or absent in six other strains of this or closely related sword-tails. The heart of fishes is not exactly comparable with that of man, but the inferior jugular vein is inverted in 10-15 per cent of these fishes normally: it was not inverted in 10-15 per cent of those with inversion of the abdominal viscera, which suggests that these latter were really examples of complete situs inversus. On the evidence available Baker-Cohen concluded that the condition was due to an autosomal gene or genes lacking full expression.

\section{Summary AND Conclusions}

Estimates for the incidence of situs inversus vary greatly. Torgersen with his wide experience finds it is 1 in 10,000 and Lowe and McKeown 1 in 7000. My calculations suggest that about 1 in 4 of the subjects with situs inversus has other malformations of the heart as well.

There are few estimates for the incidence of isolated dextrocardia and isolated lævocardia, but from my figures and those of Berri and of Lowe and McKeown, that of isolated dextrocardia is probably between 1 in 17,500 and 1 in 29,000, and that of isolated lævocardia about 1 in 22,000.

Details about the families of 40 subjects with situs inversus totalis or isolated dextrocardia or isolated lævocardia, all of whom had other malformations of the heart, have been reported and compared with the findings of Cockayne, of Lowe and McKeown, and of Lamy et al. and with the much larger series of Torgersen, most of the latter having situs inversus with a heart that was otherwise normal.

As regards their distribution in the family and the high incidence of cousin marriages between their parents, all these groups seem to behave in the same way. Cockayne's view that they were all inherited in an autosomal recessive manner cannot be entirely right, because it is not the rule that both of a pair of monozygotic twins are concordant for this. Nevertheless, their concordance is so much more frequent and the incidence of cousin marriages is so much higher ( 5 per cent) with situs inversus than with other malformations of the heart that recessive inheritance appears to play a large part in its causation, although environmental factors also must be important. This is true for situs inversus whether it is the sole lesion or whether there are other malformations of the heart as well, almost certainly for isolated dextrocardia, and probably for isolated lævocardia also.

Ivemark's syndrome of splenic agenesis and cono-truncal malformations has been considered shortly because it so often occurs with some form of situs inversus. The association suggests that some teratogenic factor may be at work between the 10th and 15th day and between the 31st and 36 th days of intrauterine life in this syndrome, though not in all cases of situs inversus.

\section{REFERENCES}

Arge, E. (1960). Transposition of the viscera and sterility in men. Lancet, 1, 412.

Baker-Cohen, K. F. (1961). Visceral and vascular transposition in fishes and a comparison with similar anomalies in man. Amer. J. Anat., 109, 37.

Bell, J. (1940). A determination of the consanguinity rate in the general population of England and Wales. Ann. Eugen. (Lond.), 10, 370.

Berg, J. M., Crome, L., and France, N. E. (1960). Congenital cardiac malformations in mongolism. Brit. Heart J., 22, 331.

Berri, G. G. (1958). Dextrocardias y Levocardias. Talleres Graficos Didot, Luca, Buenos Aires.

Bremer, J. L. (1932). The presence and influence of two spiral streams in the heart of the chick embryo. Amer. J. Anat., 49, 409.

Campbell, M. (1961). Twins and congenital heart disease. Acta Genet. med. (Roma), $10,443$.

(1962). Factors in the ætiology of pulmonary stenosis. Brit. Heart J., 24, 625.

- and Polani, P. E. (1961a). The ætiology of coarctation of the aorta. Lancet, 1, 463.

- (1961b). Factors in the ætiology of atrial septal defect. Brit. Heart J., 23, 477.

Cockayne, E. A. (1938). The genetics of transposition of the viscera. Quart. J. Med., 7, 479.

Fuhrmann, W. (1958). Diskordantes Auftreten angeborener Angiokardiopathien bei eineügen $Z$ willingen. $Z$. menschl. Vererb.- $u$ Konstit.-Lehre, 34, 563.

Ivemark, B. I. (1955). Implications of Agenesis of the Spleen on the Pathogenesis of Cono-Truncus Anomalies. Ivar Hæggströms Boktryckeri, Stockholm. (And as Supplement no. 104 to Vol. 44 of Acta padiat., 1955).

Lamy, M., de Grouchy, J., and Schweisguth, O. (1957). Genetic and non-genetic factors in the ætiology of congenital heart disease: a study of 1188 cases. Amer. J. hum. Genet., 9, 17.

Lenz, F. (1919). Die Bedeutung der statistisch ermittelten Belastung mit Blutsverwandtschaft der Eltern. Münch. med. Wschr., 66, 1340. 
Lowe, C. R., and McKeown, T. (1954). An investigation of dextrocardia with and without transposition of the abdominal viscera. Ann. Eugen. (Lond.), 18, 267.

Maynard-Smith, S., Penrose, L. S., and Smith, C. A. B. (1961). Mathematical Tables for Research Workers in Human Genetics. Churchill, London.

Polạni, P. E. (1961). Turner's syndrome and allied conditions. Brit. med. Bull., 17, 200.

_- and Campbell, M. (1955). An ætiological study of congenital heart disease. Ann. hum. Genet., 19, 209.

$-\ldots,-(1960)$. Factors in the causation of persistent ductus arteriosus. Ann. hum. Genet., $24,343$.

Polhemus, D. W., and Schafer, W. B. (1952). Congenital absence of the spleen: syndrome with atrioventricularis and situs inversus. Pediatrics, 9, 696.

Putschar, W. (1934). Die Entwicklungsstörungen der Milz. Quoted by Ivemark (1955).

Roberts, J. A. F. (1955). Cousin marriage. Med. J. S.-W., 70, 142.

Sayers, Dorothy (1933). The image in the mirror. In Hangman's Holiday. Gollancz, London.

Streeter, G. L. (1948). Developmental horizons in human embryos: description of age groups XV, XVI, XVII, and XVIII. Contr. Embryol. Carneg. Instn, 32, No. 211, p. 134.

Tihen, J. A., Charles, D. R., and Sippel, T. O. (1948). Inherited visceral inversion in mice. J. Hered., 39, 29.

Torgersen, J. (1946). Familial transposition of viscera with preliminary remarks on genetics and the correlation with diseases of the respiratory tract. Acta med. scand., 126, 319.

(1950). Situs inversus, asymmetry and twinning. Amer. J. hum. Genet., 2, 361.

Uchida, I. A., and Rowe, R. D. (1957). Discordant heart anomalies in twins. Amer. J. hum. Genet., 9, 133. 